\title{
HaRd Choices and Soft Law: Ethical Codes, Policy Guidelines and THe Role of THE Courts in Regulating Government
}

\author{
LORNE SOSSIN" AND CHARLES W. SMITH“
}

The authors examine a number of examples of "soft law": written and unwritten instruments and influences which shape administrative decisionmaking. Rather than rendering bureaucratic processes more transparent and cohesive, or fostering greater accountability and consistency among decision-makers, "soft law" in this context frequently reinforces artificial divisions. Moreover. it insulates decisions and decision-makers from the kinds of critical inquiry typically associated with "hard law." If it is to realize its potential as a bridge between law and policy, and lend meaning to core principles - like fairness and reliability soft law ought to be subjected to similarly critical consideration. The authors maintain that doing so allows one to preserve soft law's promise of flexibility. Moreover, one avoids falling prey to the misleading dichotomies soft law tends to bolster in the absence of critical administrative, political, and judicial scrutiny.
Les auteurs examinent un certain nombre d'exemples de "directives n'ayant pas de caractère obligatoire»: instruments écrits et non écrits et autres facteurs qui servent à la prise de décision administrative. Au lieu de rendre les procédés bureaucratiques plus transparents et plus cohésifs. ou d'encourager une responsabilisation et cohésion entre les décideurs, dans ce contexte, ces directives renforcent souvent les divisions artificielles. De plus, elles isolent les décisions et les décideurs des genres d'enquètes critiques que l'on associe habituellement à la urègle absolue". Pour réaliser leur potentiel de faire le pont entre la loi et la politique et d'apporter un sens aux principes de base comme lëquité et la fiabilité. ces directives doivent faire l'objet de beaucoup de critigues semblables. Les auteurs estiment qu'en ce faisant. on préserve la souplesse de ces directives. De plus, on évite de tomber dans le piège des dichotomies fallacieuses que ces directives ont tendance $\dot{a}$ hausser en l'absence d'une évaluation critique administrative, politique et judiciaire.

\section{TABLE OF CONTENTS}

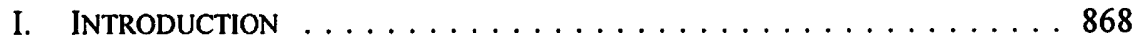

II. A BRIEF GUIDE TO GUIDELINES $\ldots \ldots \ldots \ldots \ldots \ldots \ldots \ldots 871$

III. ETHICS, SOFT LAW, AND THE POLITICS OF

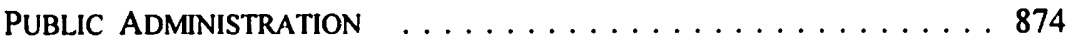

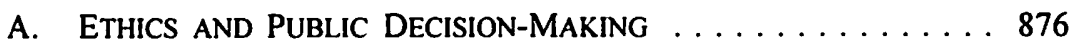

IV. SOFT LAW AND THE REgUlation OF PUBLIC ADMINISTRATION THROUGH THE COURTS $\ldots \ldots \ldots \ldots \ldots \ldots 884$

A. THE LEgal Status of SOFT LAW $\ldots \ldots \ldots \ldots \ldots \ldots 85$

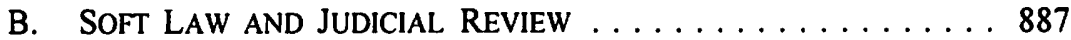

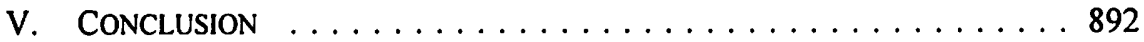

Associate Professor, Faculty of Law, University of Toronto.

- Ph.D. Candidate, Department of Political Science, York University. A version of this article was presented to the Canadian Political Science Association Annual Meeting, University of Toronto (31 May 2002). We are grateful to those who attended the conference presentation and provided comments on the article. In addition, we wish to thank Ian Greene for his constructive suggestions. We wish to acknowledge the generous financial support of the Social Science and Humanities Research Council of Canada and the Faculty of Law, University of Toronto. We are also indebted to Rosanna Langer, who provided superb research assistance and collaborated on the early stages of the article's development. 


\section{INTRODUCTION}

Accountability, impartiality, and fairness are central concerns both for administrative law and public administration. Increasingly, governments are addressing these concerns by developing codes of ethics and policy guidelines to govern the conduct and decisionmaking of public officials. In this article, we argue that these ethical codes and policy guidelines may obscure more than they reveal about administrative decision-making. These instruments, which we term "soft law," have the potential for rendering discretionary judgments more transparent and coherent. However, in our view, this potential is frustrated by a series of misleading dichotomies - between ethics and discretion, politics and administration, and law and discretion - around which the legal and administrative treatment of codes and guidelines is organized. It is first necessary to move beyond these dichotomies in order to realize the potential of soft law to enhance accountability, impartiality, and fairness in administrative decision-making.

Ethical codes and policy guidelines vary across different political and bureaucratic settings. They are sometimes developed in response to external pressures and sometimes due to internal initiative. Still other bureaucratic settings have no codes of ethics or policy guidelines at all. This ad hoc development of codes and guidelines calls into question the accountability, coherence, and fairness of public administration across Canada. For instance, who develops these guidelines, according to what processes, and for what objectives? To what extent are they binding or enforceable? In what circumstances are they made publicly available? In this analysis, we look behind the language of the ethical codes and policy guidelines to uncover their purposes and politics.

While ethical codes can be enacted in statutory form, ${ }^{1}$ in this analysis we are concerned primarily with non-legislative ethical codes and policy guidelines. They are not laws passed by the legislature. Rather, they are issued by particular departments, ministries, or public-sector institutions, as an internal constraint on, or guide for, bureaucratic decision-making. In other words, they are developed by and applicable to unelected officials exercising public authority. Codes of ethics typically set out conduct which is prohibited, based on pecuniary or associational conflicts of interest, and identify circumstances in which a public official must disclose certain information or take certain remedial steps to prevent a prohibited conflict from arising. ${ }^{2}$ Policy guidelines are non-legislative instruments which purport to assist with decision-making, rather than defining permitted or prohibited conduct. ${ }^{3}$ Typically, these guidelines take

1 See, e.g., Ontario's Members Integrity Act, 1994, S.O. 1994, c. 38, which also created the position of Integrity Commissioner and a complaints mechanism. An analogous ethics regime had first been established in Ontario in the late 1980s.

$2 \quad$ See, e.g., Industry Canada, "Conflict of Interest and Post-Employment Code for Public Office Holders" (Ottawa: Office of the Ethics Counsellor, 1994), online: Industry Canada <strategis.ic.gc.ca/SSG/oe00002e.html> (date accessed: 13 May 2002).

$3 \quad$ Policy guidelines may also be expressly authorized by statute. For example, s. 27(2) of the Canadian Human Rights Act, R.S.C. 1985, c. H-6, confers on the Canadian Human Rights Commission the express authority to create binding guidelines for the interpretation of statutory powers. Such guidelines have been issued to deal with specific standards of pay equity, among 
a statutory power or powers as a point of departure and elaborate how that discretion should be exercised in different factual settings. Ethical codes and policy guidelines form a part of the vast body of non-legislative policy instruments which constrain the exercise of administrative discretion and bureaucratic conduct. This is crucially important given the often broad and vague grants of discretionary authority to public officials, and the lack of institutional mechanisms for reviewing administrative decisionmaking.

As noted above, guidelines and codes are a species of what is sometimes termed "quasi-legislation"4 or, as we prefer, "soft law." Enacted legislation and regulations may be subject to public scrutiny in a variety of ways: parliamentary debate, public hearings, notice and comment requirements, judicial review; soft law tends to be developed and applied within the government's policy-making apparatus, with little if any input or scrutiny from the public. To the extent this has given rise to concerns, the lack of procedural and substantive constraints on government in the development of soft law is justified by the fact that these instruments cannot bind decision-makers. The Ontario Court of Appeal in Ainsley Financial Corp. v. Ontario Securities Commission described the "Rubicon between a non-mandatory guideline and a mandatory pronouncement having the same effect as a statutory instrument." Where this Rubicon is crossed (as it was by the O.S.C. in Ainsley), the Court will strike down the guideline as an unlawful fetter on the legislative discretion. ${ }^{7}$ Soft law cannot in theory bind decision-makers, yet in practice it often has as much or more influence than legislative standards. For this reason, we believe it is important for the legal regulation of discretion to proceed not from technical exercises in jurisdictional line-drawing and categorizing, but from a practical and contextual analysis of the factors that actually shape and guide decision-making.

This analysis is divided into three parts, corresponding to three central dichotomies animating the relationship between courts and government which we believe to be unfounded. In the first part, we present a brief guide to guidelines, and question the

other matters. The pay equity guidelines of the Commission are currently the subject of a judicial challenge on the grounds that they undermine the independence of the Canadian Human Rights Tribunal, on which they are binding. See Bell Canada v. Canada (Human Rights Commission), [2001] 3 F.C. 481. For an example of non-binding guidelines, see Canada, Ministry of Citizenship and Immigration, "Inland Processing Manuals," online: <www.cic.gc.ca/manuals-guides/english/ ip-e/index.html> (date accessed: 13 May 2002).

See G. Ganz, Quasi-Legislation: Recent Developments in Secondary Legislation (London: Sweet \& Maxwell, 1987) at 16-22.

The relationship between "soft" law in the form of guidelines, codes, rules, directives, as well as established policies and practices, and "hard" law in the form of statutes and regulations is analogous to the relationship between hardware and software in computers. Hardware provides the infrastructure which is uniform to all users while software must adapt to the user and enable programs to work. This term was also adopted in the context of codes of ethics in A. Campbell \& K.C. Glass, "The Legal Status of Clinical and Ethics Policies, Codes, and Guidelines in Medical Practice and Research" (2001) 46 McGill L.J. 473.

- (1994), 21 O.R. (3d) 104 at 109 [hereinafter Ainsley].

7 For discussion of this principle, see Maple Lodge Farms v. Canada, [1982] 2 S.C.R. 2 at 7; and Pezim v. British Columbia (Superintendent of Brokers), [1994] 2 S.C.R. 557 at 596. See also D. Mullan, Administrative Law (Toronto: Irwin Law, 2001) at 375-79. 
dichotomy between ethics and discretion. In our view, administrative ethics would lead to greater accountability if viewed in the context of discretionary authority generally, just as exercises of discretion should be seen in the context of the values, judgments and constraints embodied in administrative decision-makers. The dichotomy between ethics and discretion reflects an attempt to distinguish between bureaucratic conduct (governed by codes of ethics) and bureaucratic discretion (governed by policy guidelines). From a legal perspective, however, conduct and discretion are simply two sides of the same coin. All administrative acts must be authorized by law; consequently, all administrative officials are governed by judicially enforceable common law and constitutional standards which provide remedies against biased, arbitrary, or discriminatory acts. By demarcating only certain acts and biases as engaging "ethics," thereby giving rise to personal sanctions against the officials involved, codes of ethics draw artificial and misleading distinctions. ${ }^{9}$ In the second part, we examine the enthusiasm for guidelines within both government and academic circles. Here, we question the dichotomy between ethics and politics, and argue that to view ethics in an apolitical, managerial framework is inconsistent with the goal of accountability. In the third section, we examine the legal status and significance of guidelines. We challenge the dichotomy between legislation and discretionary acts, and argue that soft law itself should be subject to both internal review for consistency and coherence, and judicial review for legal sufficiency.

We conclude that soft law is poorly understood but vital to an understanding of bureaucratic decision-making. We suggest that ethical codes should not be segregated from other types of guidelines, but rather seen as part of the umbrella of administrative constraints which shape the exercise of legislative authority. Soft law, like legislation and regulations, reflects political preferences. However, because soft law is developed and applied by the bureaucracy, it is not subject to the accountability measures applicable to legislation and regulations. We believe that soft law must become a central concern for administrative law and public administration alike. The first step should be to subject soft law to some general procedural and substantive criteria in order to ensure that the legal and administrative regulation of bureaucratic decisionmaking enhances, rather than inhibits, the goals of accountability, impartiality and faimess.

* Ethical codes typically do not define ethics, although it is possible to infer a definition from examining the scope of conduct included in a code. For example, if a code prohibits only monetary conflicts of interest, one may infer that monetary conflicts are viewed in that context as engaging "ethics" while other types of conflicts of interest, such as ideological or religious conflicts, do not. It is not the intent of this article to offer an exhaustive definition of ethics. For the purposes of this study, ethics may be understood as the application of values and moral judgment to the decisionmaking process.

Our focus in this analysis is on administrative decision-making. There is a category of administrative ethics which does not pertain to decision-making, such as post-employment conduct and confidentiality concerns, which are a distinct concern and may be dealt with as part of the employment contract of civil servants or as part of a larger statutory regime for the regulation of labour relations within the public service. 


\section{A BRIEF Guide to Guidelines}

What we have termed "soft law" includes any written or unwritten rule which has the purpose or effect of influencing bureaucratic decision-making in a non-trivial fashion. Soft law is the principle administrative mechanism used to elaborate the legal standards and political values underlying bureaucratic decision-making. D.J. Galligan has written, "The most rudimentary requirements of political morality are that in exercising discretionary powers, officials should comply with standards of rationality, purposiveness and morality; from these, more specific legal principles of accountability can be developed."10 Accountability must not only be principled, however. It must also be practical. In administrative settings of high volume and scarce resources where written reasons are rare and the judgments officials make have significant consequences both for public resources and for individual and group interests - codes and guidelines may provide the only meaningful constraint on bureaucratic authority.

Given its importance to the accountability of bureaucratic decision-making, it is revealing that soft law may come in so many forms. Rules, manuals, directives, codes, guidelines, memoranda, correspondence, circulars, protocols, bulletins, employee handbooks and training materials all may have a substantial influence over decisionmaking. While it is possible to classify soft law according to its form or function (for example, to elaborate alternatives for decision-makers, or to limit them to a particular course of action), neither approach on its own results in a satisfactory framework." That a guideline comes in the form of an interpretation bulletin rather than a code of conduct, for example, tells one little about the degree of influence the guideline has over a decision-maker. Similarly, if all one considered was the degree of influence, one would learn little about whether such guidelines are intended to codify common practices, change professional norms, or provide accountability to the public. In our view, form and functional considerations cannot be disentangled, and both are significant.

The importance of an integrated approach to the role of soft law can be illustrated by a brief consideration of decision-making on humanitarian and compassionategrounds applications in the immigration and refugee setting. In this setting, as elsewhere, public officials discharge a statutory mandate. This mandate, contained for the most part in the Immigration Act, ${ }^{12}$ the Citizenship Act, ${ }^{13}$ and Regulations to these statutes, often compels particular kinds of contacts that might otherwise be considered unethical. As a general rule, it would be unlawful for an immigration officer to permit a person who is in Canada illegally to remain in the country because the Press, 1986) at 4-5.

" One attempt at a "functional" approach to classification divided guidelines into the following categories: procedural rules, interpretive guides, instructions to officials, prescriptive/evidential rules, commendatory codes, voluntary codes, rules of practice, management and operation, and administrative pronouncements. See R. Baldwin \& J. Houghton, "Circular Arguments: The Status and Legitimacy of Administrative Rules" [1986] P.L. 239 at 240-45. 
claimant has compelling compassionate circumstances. Section 114(2) of the Immigration Act, however, provides a statutory exemption to individuals from the operation of the Act on "humanitarian and compassionate" grounds, which was the subject of the 1999 Supreme Court decision in Baker v. Canada (Minister of Citizenship and Immigration), discussed further below. ${ }^{14}$ The case concerned an application by a woman who was in Canada illegally for permission to stay on the "humanitarian and compassionate" grounds that she had had four children while in Canada who were Canadian citizens, and that if deported, she would be separated from her family. The Court quashed the decision of the immigration officer, who had denied the application. Among other grounds, the Court held that the officer had failed to exercise his discretion in a humanitarian and compassionate fashion.

The Court was led to this conclusion, in part, based on its review of the nonlegislative guidelines published by the ministry to guide officials in exercising this discretion. Guideline $9.05,{ }^{15}$ for example, directed officers to carefully consider all aspects of the case, using their best judgment and asking themselves what a reasonable person would do in such a situation. It also states that, although officers are not expected to delve into areas which are not presented during examination or interviews, they should attempt to clarify possible humanitarian grounds and public-policy considerations even if these are not well articulated. ${ }^{16}$ According to the Court, the guidelines also set out two bases upon which the discretion conferred by s. 114(2) and the regulations should be exercised: public-policy considerations, and humanitarian and compassionate grounds. Public-policy reasons included marriage to a Canadian resident; the fact that a person has lived in Canada, become established, and has become an "illegal de facto resident"; and the fact that the person may be a long-term holder of employment authorization, or has worked as a foreign domestic. Humanitarian and compassionate grounds included whether unusual, undeserved, or disproportionate hardship would be caused to the person seeking consideration if he or she had to leave Canada.

Following the decision in Baker, the Ministry published an "operational memorandum" on the case and its implications for future decision-making. ${ }^{17}$ Further, training sessions were provided to allow officials to discuss how their own values and administrative culture shape decision-making on "humanitarian and compassionate"

it [1999] 2 S.C.R. 817. Section 114(2) of the Immigration Act, supra note 12, reads as follows: The Governor in Council may, by regulation, authorize the Minister to exempt any person from any regulation made under subsection (1) or otherwise facilitate the admission of any person where the Minister is satisfied that the person should be exempted from that regulation or that the person's admission should be facilitated owing to the existence of compassionate or humanitarian considerations.

Issued as part of Inland Processing Manuals, supra note 3.

Ibid.

See Baker, supra note 14; Canada, "Issues Addressed and Impact on Citizenship and Immigration Canada," <www.cic.gc.ca/manuals-guides/english/om-web/2000/ip/ip00-08e.html> (date accessed: 13 May 2002). 
grounds applications. ${ }^{18}$ In addition, subsequent scholarship has questioned whether a general governmental duty to promote human rights might lead to incorporating international human rights norms directly into future policy guidelines in light of Baker. Immigration officials would then be required to take international law norms into consideration when exercising their discretion as well. ${ }^{19}$

Immigration and Refugee officials are currently subject to additional formal and informal ethics regimes. The federal government's "Conflict of Interest and PostEmployment Code for Public Office Holders" provides, for example, that all federal civil servants must act with "integrity, objectivity and impartiality," and that "public office holders, in fulfilling their official duties and responsibilities, shall make decisions in the public interest and with regard to the merits of each case." ${ }^{20}$ In addition, the Ministry is governed by its own "Code of Conduct," which sets out prohibited conflicts, sanctions against sexual harassment, and so forth. Finally, an innovative ministry initiative which involved consultations with all Ministry staff led to the publication in December 1998 of The Ethical Compass: a compendium of complex, hypothetical case studies which engage the values and judgment of immigration and refugee officials in applying the statutory authority, rules and guidelines to particular circumstances. ${ }^{21}$ In introducing these cases, Jeff Le Bane, Chair of the ministry's Values and Ethics Steering Committee, noted the following:

[O]ur immigration system is codified to a large extent, but much discretion remains. Incidents arise that are not covered by set rules or where the rules themselves seem contradictory. In these cases, staff are left to exercise their best judgment. These judgments are based on our corporate values and ethics.

Our workplace values are the standards we set for our interactions with our clients and with each other. Our public service values include professionalism, honesty and fairness. Our ethics are the way we put our values to work in actual decision making, that is, doing the right thing.

Ideally, our workplace values and ethics should be in harmony with our personal convictions and beliefs if we are to feel comfortable with the work we do. Personal convictions and beliefs, however. do not replace workplace values and ethics. Our position as public servants requires us to have corporate values and ethics that we can communicate to the public and on which the public can rely.

18 One such training session, entitled "Baker and Beyond," was hosted by York University's Centre for Practical Ethics in February 2001, and included lectures on the case and its implications, as well as workshops at which immigration and refugee officials were exposed to various hypothetical fact scenarios engaging the issues and values touched upon in the case. international des droits de la personne en droit iterne" (2002) 27 Queen's L.J. 511. Supra note 2 at ss. $1,3$.

21 Citizenship and Immigration Canada, The Ethical Compass (Ottawa: Citizenship and Immigration Canada, 1998), online: <www.cic.gc.ca/english/pub/values-e.html> (date accessed: 13 May 2002) [emphasis in original] [hereinafter The Ethical Compass]. 
Values and ethics are clearly at the core of everything we do as public servants. They are the "glue" that binds us together. It is in the grey areas, however, that we most need to clarify our corporate values and ethics. This is what has led us to an initiative devoted to dilemmas. ${ }^{22}$

Interestingly, of the fifteen cases discussed in The Ethical Compass, a consensus response was presented for virtually all the scenarios. A notable exception was the scenario which called upon the official to balance program responsibility with compassion to an individual claimant - precisely the issues on which the Baker case turned. As the immigration and refugee setting suggests, ethics must be seen as broader than a particular form (a code or set of rules) intended to perform a particular function (avoid conflicts of interest). Ethics are engaged whenever the values, morals and judgment of public officials play a significant role in the exercise of public authority. In this sense, just as all ethical codes should be seen as components of the larger array of soft law, soft law should be seen as an element of the larger array of ethical influences which govern an official's judgment. Finally, whenever one is concerned with constraints on administrative decision-makers, one must consider institutional as well as individual contexts. Soft law highlights the way in which institutional dynamics and individual judgment combine in the exercise of discretion.

Consequently, the distinction between ethical codes which relate to conduct, and guidelines which relate to discretionary decision-making is, in our view, misleading and undesirable. It suggests that some discretionary judgments involve ethics, whereas others involve the application of mere technical expertise or straightforward legal requirements. ${ }^{23}$ In reality, the discretionary judgments of public officials reflect a complex set of legal, administrative, political, cultural and personal influences. Given the artificiality of this distinction between ethics on the one hand, and discretion on the other, it is puzzling that political scientists have devoted such a substantial literature to the value of codes of ethics while devoting little or no attention to other forms of soft law, and the political preferences encoded in guidelines generally.

\section{Ethics, Soft Law, and the Politics of Public Administration}

Within the past two decades a robust literature on ethical guidelines has emerged in the political science and public administration fields. This literature has linked the morality and ethics of public officials to the institutional parameters of the state. The attention to ethics has corresponded with a fundamental transformation of Canadian government, at all jurisdictional levels, from traditional forms of public administration

bid at 3-4.

To clarify, our critique applies to ethical codes which establish standards for government decisionmaking, whether in relation to government contracts, procurement, or conflicts of interest. Other provisions in ethical codes which relate exclusively to the honesty and integrity of public officials, or those which relate to post-employment activities, fall outside the scope of our analysis. While such standards clearly have a place in the regulation of public officials, this is more appropriately dealt with in human resources and employment settings such as contracts of employment or terms of appointments. 
to a "new public management" paradigm. ${ }^{24}$ Integrated within this conversion has been a shift in the classic Westminster regime values of parliamentary accountability and responsible government to a more neo-liberal-oriented public sector, in which accountability is focused on the discourse of client-centred government, manager empowerment, and flexible service delivery. ${ }^{25}$ Although this transformation has stimulated a radical restructuring of public-service culture, both reformers and traditionalists continue to emphasize the importance of written ethical guidelines in directing administrative discretion and enhancing democratic accountability. ${ }^{26}$ In this regard, non-legislative ethical tools which structure the growth of soft law principles play a prominent political role in shaping (and reshaping) administrative culture.

Nonetheless, within much of the political science and public administration literature, the benefits of ethical guidelines tend to be viewed in non-contested, apolitical terms. Rarely is the process by which guidelines are developed and issued the subject of public scrutiny. Whether stakeholder groups or other interested segments of the public should have a consultative role; whether some or all staff of a particular ministry or department should be consulted; whether guidelines should meet any procedural requirements: these and other important questions remain unasked. Rather, the practice of public administration is viewed within this literature as a duality between ethical and unethical conduct. Guidelines are intended to clarify the dividing line between these two categories, whether in the context of conflicts of interest, lobbying, confidentiality principles, or the vague but lofty obligation to act "in the public interest." ${ }^{27}$ The enforcement of these provisions has been largely maintained through a quasiindependent auditor or ethics commissioner, although the precise authority of these

24 This has been a central focus of the recent debates regarding public administration and ethics in the past decade. See Canadian Centre for Management Development, A Strong Foundation: Report of the Task Force on Public Service Values and Ethics, Discussion Paper by J. Tait (Ottawa: Canadian Centre for Management Development, 1997) at 1-39 [hereinafter A Sirong Foundation]. See also K. Kernaghan, "The Emerging Public Service Culture: Values, Ethics, and Reforms" (1994) 37 Can. Pub. Admin. 614.

25 O.P. Dwivedi and Iain Gow identify the classic regime values of the Canadian public service with the 1908/1918 civil service reform acts which created a civil service based upon the values of merit, political neutrality, anonymity, secrecy, and accountability. By contrast, new public management values have been linked to structural reforms based on the principles of innovation, decentralization, efficiency, flexibility and client service. See O.P. Dwivedi \& I. Gow, From Bureaucracy to Public Management: The Administrative Culture of the Government of Canada (Peterborough: Broadview Press, 1999) at 66-80, 126-29. For a broader understanding of the new public management theory, see D. Osborne \& T. Gaebler, Reinventing Government: How the Entrepreneurial Spirit Is Transforming the Public Sector (Reading: Addison-Wesley, 1992).

26. K. Kernaghan \& J.W. Langford, The Responsible Public Servant (Ottawa: Institute for Research on Public Policy, 1990) at 183-94 [hereinafter Responsible Public Servant].

27 See, e.g., the recommendations by K. Kernaghan, Ethical Conduct: Guidelines for Government Employees (Toronto: Institute of Public Administration of Canada, 1975) (hereinafter Ethical Conduct]. See also the conclusions of M.M. Atkinson \& M. Mancuso, "Do We Need a Code of Conduct for Politicians? The Search for an Elite Political Culture of Corruption in Canada" (1985) 18 Can. J. Pol. Sci. 459. 
bodies is by no means clear. ${ }^{28}$ Indeed, in some cases, the goal of ethical guidelines appears not so much to govern conduct as to instill a service-oriented, professional ethos within the sphere of public work. As noted in The Ethical Compass - referred to above in the context of immigration and refugee decision-making - "the manager becomes the coach and advisor rather than the taskmaster, and the motivation, productivity, and job satisfaction of employees rise." 29 The link between ethical guidelines, public sector work, and the principles guiding new public management is discussed below.

In examining the literature regarding ethical guidelines and bureaucratic conduct, it is important to ask whether the current popularity of written ethical guidelines and codes implies a greater commitment to public service democracy or accountability? Of course, the answer to this question depends on how the problem of administrative ethics is framed generally. If one views ethics within the broader framework of the legal regulation of discretionary decision-making, the codes of ethics advocated in the political science literature appear narrow and one-dimensional. However, if one views ethics as a reflection of administrative culture, the act of setting out collective aspirations and expectations in written and widely disseminated codes may well represent a progressive attempt at improving the quality of public administration. As with goals like justice and integrity, there are few critics who wish to see less rather than more ethics in government.

\section{A. Ethics and Public Decision-Making}

The popularity of ethics can sometimes mask the contested nature of the term and its implications. According to Ian Greene and David Shugarman, ethical conduct "concerns the way people ought to act in their relations with one another." ${ }^{30}$ Stemming from this interaction, Greene and Shugarman argue that ethical rules, guidelines, and procedures are grounded in the liberal principle of mutual respect. Mutual respect, in turn, is grounded in a theory of justice which requires that ethical decision-making be grounded in a toleration for all cultural and individual interests. ${ }^{31}$ Consequently, public

See the mandate of the quasi-independent Canadian Ethics Counsellor, which is limited to overseeing two related domains: conflict of interest and lobbying. In overseeing these areas of political interest the federal Ethics Counsellor reports directly to the Prime Minister and Cabinet, not to Parliament. This limitation lessens the potential for Ethics Counsellors to effect lasting change on the politics of Parliament. The Ethics Counsellor also has authority over the "Conflict of Interest and Post-Employment Code for Public Office Holders," supra note 2. For a broad overview regarding the enforcement guidelines of the office of the Ethics Counsellor, see Canada, "Office of the Ethics Counsellor," online: <strategis.ic.gc.ca/SSG/0e0000le.html> (date accessed: 13 May 2002). See generally I. Greene, "Government ethics commissioners: the way of the future?" (1991) 34 Can. Pub. Admin. 165.

:The Ethical Compass, supra note 21.

I. Greene \& D.P. Shugarman, Honest Politics: Seeking Integrity in Canadian Public Life (Toronto: James Lorimer, 1997) at 2.

" Despite the complex theoretical questions which have emerged from the theoretical works of Aristotle, Machiavelli, Locke, Hobbes, Kant, Hegel and Marx (to name but a few), we are more concerned here with the practical relationship between ethical codes and administrative discretion. For a brief introduction to the contemporary liberal theorists, however, see J. Rawls, A Theory of 
officials should act in a neutral manner when deciding individual cases and not show favour to any individual or group over another. This link between ethics and impartiality is critical (although within a framework of mutual respect, it is of course possible to interpret governmental obligations as requiring that public officials show greater favour to particular, disadvantaged, or vulnerable groups). ${ }^{32}$ Assuming impartiality is a cornerstone of ethical behaviour, it follows that any form of bias in administrative decision-making - whether attitudinal, associational, ideological, pecuniary or otherwise - constitutes unethical conduct. Yet if this is the case, as suggested above, codes of conduct appear to obscure more than they reveal about the scope of impartiality.

While it is true that other legal devices extend to cover the settings of bias left out of codes of ethics (such as the reasonable apprehension of bias doctrine at common law, the procedural protections contained in s. 7 of the Charter ${ }^{33}$ and s. 2(e) of the Bill of Rights ${ }^{34}$ ), it is equally true that those doctrines also cover much of what is included in codes of ethics (such as criminal sanctions for fraud and corruption). ${ }^{35}$ While the liberal democratic ideals of mutual respect provide an important link between ethics and the principles of equality before the law, deference to the majority, protection of minority rights, and so on, it is not clear precisely what these codes add to the legal obligations on public decision-makers to act impartially, in the public interest, and abiding the rule of law, the Charter, and the legal doctrine of administrative fairness. ${ }^{36}$

This theoretical approach to ethical decision-making has a broad appeal in much of the public administration literature, primarily because of the desire to legitimate the discretionary authority exercised by unelected officials. ${ }^{37}$ In most western democracies, this power has been justified through a commitment to the traditional model of scientific administration, which sought to create a strong division between political

Justice (London: Oxford University Press, 1971). For a more critical yet similar argument see W. Kymlicka, Liberalism. Community and Culture (Oxford: Clarendon Press, 1989) at 59-60, 81-83. See, e.g., L. Sossin, "An Intimate Approach to Faimess, Impartiality and Reasonableness in Administrative Law" (2002) 29 Queen's L.J. 809.

Canadian Charter of Rights and Freedoms, Part I of the Constitution Act, 1982. being Schedule B to the Canada Act 1982 (U.K.), 1982, c. 11 [hereinafter Charter].

is

\section{Canadian Bill of Rights, S.C. 1960, c. 44, reprinted in R.S.C. 1985. App. III.}

See, e.g., R. v. Hinchey, [1996] 3 S.C.R. 1128, in which the Court set out the scope of the anticorruption provisions in the Criminal Code, R.S.C. 1985, c. C-46, s. 121(1)(c).

See Baker, supra note 14 at para. 56. The duty of faimess is a common law obligation which imposes specific procedural requirements - notice, disclosure, hearing, cross-examination, written reasons, rights to an appeal, etc. - in particular circumstances where a final, non-legislative decision may adversely affect the rights, interests, and privileges of a person. See J. Evans et al., eds., Administrative Law: Cases, Text and Materials, 4th ed. (Toronto: Emond Montgomery, 1995) at 45-202. See also M.J. Bryant \& L. Sossin, Public Law: An Overview of Aboriginal, Administrative, Constitutional and International Law in Canada (Toronto: Thomson Canada. 2002) 150-95.

J.A. Rohr, "Preface," in Ethics for Bureaucrats: An Essay on Law and Values, 2d ed. (New York: Marcel Dekker, 1989). See also R.A. Chapman, "Ethics in Public Service," in R.A. Chapman, ed., Ethics in Public Service (Ottawa: Carleton University Press, 1993) 155. 
action and public administration. ${ }^{38}$ Pursuant to this politics-administration dichotomy, bureaucratic actors are perceived as professional policy implementers, while elected representatives remain the legitimate creators of public policy. Although no scholar of public administration would argue that such a dichotomy is fully sustainable in the highly complex administrative framework of modern states, it has been argued by Reg Whitaker that such a principle can act as an unwritten ethical guide to structure administrative decision-making in accordance with democratic standards. ${ }^{39}$ Such principles include the conventional doctrine of parliamentary and public sector accountability, and incorporate merit, political neutrality, anonymity, secrecy, and loyalty. These traditional parliamentary conventions have been designed so as to ensure that professional administration is protected from political interference. ${ }^{40}$ In order to maintain this division, the modern bureaucracy has been structured along Weberian principles designed to promote rational decision-making through a hierarchal administrative structure maintained through a strict division of labour. ${ }^{41}$ In return, elected officials are supposed to maintain the fundamental values of responsible government, which guarantees that a cabinet minister maintains political responsibility for the actions of his or her ministry. ${ }^{42}$ This legal fiction holds that bureaucratic actors work in the loyal service of government, thus ensuring a hierarchal line of accountability between elected ministers and unelected bureaucrats.

As a variety of critics have been quick to observe, however, legal fictions cannot guarantee ethical behaviour. Dennis Thompson, for instance, has argued that the traditional institutionalist analysis of administrative ethics tends to separate individual responsibility from the broader structures of organizational culture. ${ }^{43}$ Thompson contends that the Weberian model of public bureaucracy which links institutional structure to the neutrality of public servants acts as a shield to protect individual administrators from their moral public duty. ${ }^{44}$ These institutional barriers downplay the overall authority that individual bureaucrats have within public institutions. For Thompson, then, the Weberian models of structural hierarchy and administrative neutrality act as obstacles to the possibility of public-sector ethics. In order to improve

3* For a detailed discussion see R.J.S. Baker, Administrative Theory and Public Administration (London: Hutchinson, 1972) at 21-40. See generally G. Inwood, Understanding Canadian Public Administration (Scarborough: Prentice Hall, 1999) at 4-9, 125-26.

39 See R. Whitaker, "Politics Versus Administration: Politicians and Bureaucrats" in M. Whittington \& G. Williams, eds., Canadian Politics in the 21st Century (Scarborough: Nelson Thomson Learning, 2000) 55 at 55-56.

so See Dwivedi \& Gow, supra note 25 at 66-74.

$\$ \quad$ H.H. Gerth \& C. Wright Mills, eds., From Max Weber: Essays in Sociology (New York: Oxford University Press, 1958) at 95-96, 196-97.

12 For a classic discussion on these political relationships, see J.E. Hodgetts, The Canadian Public Service: A Physiology of Government, 1867-1970 (Toronto: University of Toronto Press, 1973), 48-54. See also S.L. Sutherland, "The Public Service and Policy Development" in M. Atkinson, ed., Governing Canada: Institutions and Public Policy (Toronto: Harcourt Brace Jovanovich, 1993) 81 at $83-86$.

s: D.F. Thompson, "The Possibility of Administrative Ethics" (1985) 45 Pub. Admin. Rev. 555 [hereinafter "Administrative Ethics"].

it D.F. Thompson, "Moral Responsibility of Public Officials: The Problem of Many Hands" (1980) 74 Am. Pol. Sci. Rev. 905 at 906. 
these structures, Thompson advocates a theory of public administration which will directly link individual performance to the rubric of organizational culture. Such a requirement would encourage public servants to act in the public interest through resistance to unethical polices or, in some cases, to blow the whistle on unethical political behaviour. ${ }^{45}$ Following this reasoning, individual public servants have a personal and moral responsibility to act ethically within an organizational structure. In fact, he argues that,

To isolate more specifically the objections to administrative ethics, we should assume that the moral perspective can be vindicated and that some moral principles and some moral judgments are valid. Despite disagreement about how morality is to be justified and disagreement about its scope and contents, we nevertheless share certain attitudes and beliefs to which we can appeal in criticizing or defending public actions and policies from a moral perspective. ${ }^{46}$

In order to encourage individual ethical decision-making, Thompson supports the implementation of a formal written code of ethics, which he argues can guide individual moral behaviour within the public service. In the shift away from unwritten ethical guidelines and informal administrative constraints which typify traditional parliamentary government, Thompson argues that written codes can provide the necessary guidance for both individual bureaucrats and the general public to improve public-sector accountability.

Similar to Greene, Shugarman, and Thompson, Kenneth Kernaghan and John Langford have been strong supporters of ethical codes designed to guide and structure individual bureaucratic morality. For Kernaghan and Langford, promoting an ethical culture is essential to the public service in order to maintain a fair and just social order. ${ }^{47}$ They reject, therefore, the relativist critique which contends that there cannot be a universal right or wrong. ${ }^{48}$ Rather, following the argument of Dennis Thompson, Kernaghan and Langford assert that written ethical guidelines can promote a bureaucratic culture that promotes administrative fairness. This view asserts that ethical conduct by individual public servants is an essential ingredient to democratic governance. Kernaghan and Langford suggest that ethical conduct can be enforced through individual actors as well as the public service at large. In this regard, the authors take both a teleological (arguing that things and people exist for a purpose) and deontological (positing a duty-based theory of morality) approach to their study of administrative ethics. ${ }^{49}$ In other words, ethical conduct in the public service reflects both the personification of individual feelings of right and wrong and a broader institutional understanding of social morality.

Ibid. at 913-14. On a more general theory of whistleblowing, individual behaviour, and organizational structure, see J.L. Perry, "Whistleblowing, Organizational Performance, and Organizational Control" in H.G. Frederickson, ed., Ethics and Public Administration (Armonk: M.E. Sharpe, 1993) 79.

th "Administrative Ethics," supra note 43 at 555.

17 Responsible Public Servant, supra note 26.

s* lbid.

ง" Ibid. 
Kernaghan and Langford outline several areas which can promote a commitment to fostering an ethical public servant. Similar to Thompson, they maintain that a formal written code of ethics can elucidate the failings of traditional forms of Weberian bureaucracy. A good code, they maintain, would be a written document which represented a consensus within various organizations, departments, and ministries concerning both institutional values and behaviours to be avoided. ${ }^{50}$ It could also act as a document to educate and communicate the values of the public service to new employees and to society at large, yet stop far short of any procedural requirement that affected parties or the public generally be consulted in the development of codes of conduct. Most importantly for Kernaghan and Langford, a written code would become a fundamental component of the day-to-day management of government departments. ${ }^{51}$ In this model, such codes are viewed first and foremost as management tools. It is not surprising, therefore, that written ethical guidelines have become a central component of the new public movements designed to restructure the association between senior management, individual public employees, and the general public.

Many of the arguments surrounding public sector reform and ethical guidelines have integrated Thompson's critique of the traditional forms of bureaucratic organization, and argue that the ethical empowerment of individual public managers can enhance public sector accountability. Ethical considerations, reformers contend, can act as an important guide to incorporate the "new" relationship between public managers, employees, and clients. From this viewpoint, ethics play a fundamental role in redefining relationships between the state and markets. In fact, the Tait Task Force argued in 1997 that the ethical challenges arising from the new public management would play an important role in guiding the changing structure of the public service, including aiding in the restructuring of market-centred alternative service delivery and the contracting out of government services. ${ }^{52}$ In reaching their conclusions regarding these changing value structures, the Tait Task Force argued that the neo-liberal restructuring which occurred within the Canadian public service has altered the manner in which the public service is administered. Yet the Task Force maintained that such restructuring has not radically downplayed the quality of public service in Canada. They contend that the new public management has in many cases reinvigorated the concept of "service" into the bureaucracy. Thus, as part of their recommendations, the Task Force sought to incorporate a holistic approach between old and new bureaucratic values in such a way as to strengthen the relationship between bureaucratic discretion and the public interest. The mechanism by which the Task Force proposed to strengthen the tension between "old" and "new" values of public administration was the establishment of a servicewide regime of ethics which would act as a form of dialogue between senior public

\section{Ibid. at 187.}

Ibid. at 191-94.

s2

A Strong Foundation, supra note 24 at 29-44. As part of aiding in the new public-private partnerships associated with the NPM, the Auditor General of Canada agreed with the Tait Task Force, recommending that a code of ethics be developed specifically to monitor the relationship between the public service and the private sector. See Canada, "Values and Ethics in the Federal Public Sector" in Report of the Auditor General of Canada to the House of Commons, 2000 (Ottawa: Canadian Auditor General, 2000) at 12.3-12.43. 
managers, public employees, and citizens. ${ }^{53}$ Ethical guidelines, in turn, play an important political role in restructuring the managerialism of employee productivity and bureaucratic discretion. ${ }^{54}$

As a natural extension of these conclusions, the Task Force placed strong emphasis on the importance of individual codes of conduct as a key ingredient to strengthen bureaucratic values. These "new" challenges include rethinking the manner of clientoriented services, the empowerment and discretion of front-line workers, and the continued decentralization and downsizing of public-sector work. ${ }^{55}$ They argue that agency codes of conduct will allow public servants to express concerns about actions that are potentially illegal, unethical, or inconsistent with these new public-service values. In following much of the theoretical literature regarding ethical conduct, therefore, the Tait Task Force placed a great deal of emphasis on individual ethics as a means to bridge the gap between traditional Weberian models of bureaucracy and the neo-liberal model of market-centred administration. That being said, despite the strong emphasis on ethical codes of conduct acting as mediators between old and new publicservice values, the manner of maintaining or enforcing this new ethical regime is left to an unidentified, service-wide, independent institution designed to monitor ethical behaviour. ${ }^{56}$ This institution would presumably be integrated as a quasi-independent ethics commissioner with the mandate to oversee both a service-wide code of conduct and a set of ethical guidelines within individual departments.

According to Kernaghan, an additional benefit of ethical codes is the development of a professional ethos within the civil service. Codes of conduct, he argues, can play both a preventative and progressive role in promoting ethical conduct within the public service. The evidence for this, he maintains, has been in the successful regulation of ethics within professional associations, including the Canadian Medical Association, the Canadian institute of Chartered Accountants, and the Canadian Bar Association. Notwithstanding the critiques to which ethical codes in professional settings have been subject, ${ }^{57}$ this analogy is not particularly strong. Public servants (at least those in discretionary decision-making settings) are not a self-governing profession operating at arm's length from government, with standardized entry criteria and universal qualifications. While an ethical organizational culture among public servants is surely a desirable outcome, the inherently political nature of public administration makes the

A Strong Foundation, ibid. at 43-44. See also K. Kernaghan. The Ethics Era in Canadian Public Administration (Ottawa: Canadian Centre for Management Development, 1996) Research Paper No. 19.

s. See, e.g. the political role of managerialism within the New Public Management (NPM) identified by J. Shields \& B.M. Evans, Shrinking the State: Globalization and Public Administration "Reform" (Halifax: Fernwood Publishing, 1998) at 71-73.

53 A Strong Foundation, supra note 24 at 19-23.

s. Ibid. at 68 .

57 See. e.g., J.K. Lieberman, "Some Reflections on Self-Regulation" in P. Slayton \& M.J. Trebilcock, eds., The Professions and Public Policy (Toronto: University of Toronto Press. 1978) 89; C. Tuohy \& P. O'Reilly, "Professionalism in the Welfare State" (1992) 27 J. Can. Stud. 73: S. Koniak, "Law and Ethics in a World of Rights and Unsuitable Wrongs" (1996) 9 Can. J.L. \& Juris. 11; and M.A. Wilkinson, C. Walker \& P. Mercer. "Do Codes of Ethics Actually Shape Legal Practice?" (2000) 45 McGill L.J. 645. 
nature and scope of ethics - and the form in which they are regulated - open to fundamental debate.

In order to ensure public administrative ethics, Kernaghan analyses various occurrences of ethical dilemmas in the public service, including conflicts of interest, administrative political activity and public comment, and confidentiality.$^{58}$ Once again, absent from this catalogue of ethical dilemmas are other influences which may compromise the fairness and coherence of administrative decision-making, such as attitudinal and ideological biases; ethnic, linguistic, racial, religious, gender and class affinities; and individual political preference. For Kernaghan, the meaning of ethics is rarely contested - why does one kind of bias justify sanctions whereas another does not? The line between ethics and politics is presumed but not examined. The goal of ethical codes in his view is not so much to clarify a set of decision-making values as to constitute a value in and of itself. He concludes:

\footnotetext{
What is especially important is that those in formal positions of authority or in informal positions of influence accept the code as one standard by which an employee's conduct is assessed in connection with promotion and other rewards. The employee will be expected to achieve certain ethical standards as well as technical standards. If the employee does not "get religion," he may at least "get the message" that occupational success and congenial relations with fellow employees depend in part on his demonstrating appropriate ethical standards. Thus a code may be used both as an instrument of control and a means of influence over administrative action. ${ }^{59}$
}

In his more recent writings, Kernaghan continues to reaffirm the importance written codes of conduct can have in regulating administrative action. ${ }^{60} \mathrm{He}$ again attempts to link the importance of a written code of conduct aimed at individual actors with larger issues of societal values and culture. By making this linkage, Kernaghan is attempting to incorporate his personal belief in ethical standards and principles so that they can be applied to the resolution of value conflicts and dilemmas. ${ }^{61}$ For him, unethical conduct is a disease which must be purged. Codes of ethics are his medicine of choice. He argues that codes both "provide preventative medicine against the malady of unethical conduct and a distasteful dose of medicine for an employee who contracts the disease." ${ }^{62} \mathrm{He}$ advocates rules which govern the broad macro level of administrative decision-making with both preventative and punitive measures (such as oaths of office on one hand and reprimands, fines, and dismissal on the other) ${ }^{63}$ At a more micro level of analysis, however, the role of senior managers and individual employees can also be imperative to organize individual departments so as to incorporate the values of ethical guidelines in such a manner as to regulate administrative discretion.

Ethical Conduct, supra note 27.

Jbid. at 8.

K. Kernaghan, "Codes of Ethics and Public Administration: Progress, Problems and Perspectives" (1980) 59 Pub. Admin. 207.

Also see K. Kernaghan, "Promoting Public Service Ethics: The Codification Option" in R.A. Chapman, ed., Ethics in Public Service (Ottawa: Carleton University Press, 1993) 15.

Ethical Conduct, supra note 27 at 4-5.

Responsible Public Servant, supra note 26 at 195. 
Following from this analysis, the standard critique of ethical codes of conduct continues to be that such guidelines are vague and unclear regarding the everyday scenarios of public work. ${ }^{64}$ Yet beyond the normative dimensions of defining what is "ethical" as a category, it has the effect (whether intended or not) of turning contests over political preferences into debates about virtue and principle. Politics are supplanted by the rhetoric of managerial efficiency and competitiveness. ${ }^{65}$ In this manner, it is not so much that accountability is diminished by implementing codes of conduct; rather, the nature of that accountability is changed. A discourse of ethics tends to cleanse the politics from public administration and, consequently, obfuscate the judgments over political preferences which public officials necessarily make when exercising discretionary authority. ${ }^{66}$

When we place these political preferences under the microscope, it should come as little surprise that much of the restructuring of public-sector services has been based on a discourse of ethics. In the 1990s, for instance, the public service in the federal government and in many of the provinces was primarily concerned with the restructuring of public services. The politics of this restructuring are highly controversial, and often involve difficult decisions regarding those services that are privatized, contracted out, or downloaded to the private sector. Such decisions, by their nature, call into question the relationship that public officials in these departments have with private-sector actors. Ultimately, these decisions will blur the lines between the public and private delivery of services. The politics of neo-liberal public sector management, therefore, has attempted to divorce the politics behind these policies through a discourse of ethics and ethical conduct. Theoretically, Konstantinos Tsoukalas has argued that in an era of market liberalization of government services, this trend is inevitable primarily because the merging of public and private decision-making legitimizes the public delivery of services for a profit. ${ }^{67}$ Yet arguably, in an era of profit-driven public-private ventures, with merit incentives for civil servants based on private sector models, the line between acceptable and unacceptable pecuniary considerations is not always self-evident.

Recent events in Canada have brought renewed public scrutiny to government ethics. The furor surrounding the federal government's use of private firms in Quebec to deliver government advertising is a good example of how difficult it is to distinguish proper conduct from political preference in public-private partnerships. Evidence

K. Tsoukalas, "Globalisation and the 'Executive Committee': Reflections on the Contemporary Capitalist State" in L. Panitch \& C. Leys, eds., Global Capitalism V'ersus Democracy: Socialist Register 1999 (Suffolk: Merlin, 1999) 56 at 69-70.

See, e.g., L. Pratchett, "The Inherently Unethical Nature of Public Service Ethics" in R.A. Chapman, ed., Ethics in Public Service for the New Millennium (Aldershot: Ashgate, 2000) 111 at $112-14$.

See Shields \& Evans, supra note 54 at 53-57. See also G. Albo, "Democratic Citizenship and the Future of Public Management" in G. Albo, D. Langille \& L. Panitch, eds.. A Different Kind of State? Popular Pover and Democratic Administration (Toronto: Oxford University Press, 1993) 17 at 23-27.

B. Guy Peters, "Is Democracy a Substitute for Ethics? Administrative Reform and Accountability" in R.A. Chapman, ed.. Ethics in Public Service for the New Millennium, supra note 64, 127 at 13536. 
surfaced in the summer of 2002 that a senior civil servant with the ministry of Public Works approved $\$ 1.6$ million in federal contracts to the advertising firm of Groupaction Inc. in order to produce reports that were missing or incomplete. ${ }^{68}$ This formed part of the federal government's post-referendum strategy of raising its profile in Quebec by sponsoring sports and cultural events - a strategy implemented by awarding contracts to select private Quebec advertising firms. In response to these and other scandals, the federal government is developing a set of new ethical rules for politicians and senior bureaucrats to govern dealings with the private sector. ${ }^{69}$

The ethics discourse has sidestepped debate over the propriety of contracting out public communications services to private providers; nor has the government's political strategy in Quebec come under significant scrutiny. Rather, by framing the debate as a question of ethics, attention has shifted to whether the advertising firm which received the contract did so because of donations made to the Liberal Party, and whether valuable work was in fact done in exchange for the vast sums of money given the firm. ${ }^{70}$ Is the fact that the decision to award the contract was based on the partisan, federalist sympathies of the firm of more or less concern than the fact that the firm was a donor to the party in power? The germane question - and one rarely raised in the context of an ethical scandal - is which factors are relevant to the discretion being exercised, and which are irrelevant.

Ethical scandals also raise the ambiguous legal status of ethical codes. In response to allegations arising from the sponsorship scandal, Ralph Goodale, the new Minister for Public Works, simply stated, "The rules are there to be followed, not to be broken." ${ }^{71}$ However, as discussed in the following part, whether such rules must necessarily be followed, and the extent to which they may legitimately fetter bureaucratic decision-making, remain unsettled questions in Canadian law.

\section{SOFT LAW AND THE REgULATION OF Public Administration THROUgh the COURTS}

While soft law often proves crucially important to those affected by broad grants of statutory discretion, it has received little scholarly attention in Canada. ${ }^{72}$ As discussed above, political science scholars for the most part have limited their focus to codes of ethics as professional rules, divorced from broader constraints on administrative

D. LeBlanc, "Bureaucrat in ad furor stonewalls" Globe \& Mail (10 July 2002) Al.

B. Laghi \& C. Clark, "PM to unveil new ethical rules" Globe \& Mail (23 May 2002) A1. A proposed Code of Conduct for Parliamentarians was presented in draft form to the House of Commons and Senate on 23 October 2002. See <strategis.ic.gc.ca.SSG/oe01250e.html> (date accessed: 3 March 2003).

The senior civil servant, J. Charles Guite, now retired, has alleged that he was told to award the contracts without following normal procedures by the Privy Council Office. See D. LeBlanc, "Police Should Probe Claims" Globe \& Mail (4 October 2002) A4.

Ibid.

For some notable exceptions, see F. Houle, "La zone fictive de l'infra-droit: l'intégration des règles administratives dans la catégorie des texts réglementaires" (2001) 47 McGill L.J. 161; Mullan, supra note 7 at 375-79; and R. Dussault \& L. Borgeat, Administrative Law: A Treatise, 2d ed., trans. M. Rankin (Toronto: Carswell, 1986) vol. 1 at 338-39. 
decision-making. Legal scholars have devoted some attention to rules affecting regulatory agencies and administrative tribunals, ${ }^{73}$ but less so to the various instruments and influences that shape administrative discretion. ${ }^{74}$

It is fair to say that soft law operates below the radar screen of most administrative and constitutional law scholars. In part, this is a reflection of judicial ambivalence toward the significance and status of guidelines. Judicial attitudes are more significant in administrative settings, of course, because the principal means by which unelected officials may be held accountable for adverse discretionary decisions is through judicial review. As a general rule, courts have adopted a deferential posture to exercises of administrative discretion. By definition, if an official has been granted discretion, there is not a right or wrong decision, but a range of acceptable choices. So long as those choices are made reasonably, consistent with the purposes envisioned by the legislation, the court will not interfere. ${ }^{75}$

\section{A. The Legal Status of Soft Law}

The first Supreme Court case to consider the status of soft law was Martineau v. Matsqui Institution Inmate Disciplinary Board,$^{76}$ in which an inmate of a federal penitentiary appealed against a disciplinary order made pursuant to directives issued by the Commissioner for Penitentiaries. The governing legislation authorized the Commissioner to make rules for disciplinary purposes. The directives at issue in the case concerned procedural rights for an inmate before the Parole Board, which had the power to revoke remission points toward the early release of the inmate for disciplinary infractions. In Martineau, at issue was the Board's failure to abide by these procedural protections. Four justices held that the directives were merely "administrative" and thus could not bind the Board. Four dissenting justices held that the directives were "law" since they were authorized by the $A c t$ and affected the rights of an individual. The deciding "swing" justice, Judson J., dismissed the appeal for reasons given by the Federal Court of Appeal, which had also treated the directives as administrative in nature. For the majority, the directives themselves could not give rise to procedural rights, nor could the Board be sanctioned for not following them. Justice Pidgeon, writing for the four judges in the majority, characterized the directives in the following terms:

See, e.g., Evans et al., supra note 36 at $359-80$.

Supra note 72. Houle is not interested in the effect of policy guidelines on discretionary decisionmakers per se, but rather in the status of such guidelines as "law," and more specifically whether they should be subject to the requirements of the Statutory Instruments Act, R.S.C. 1985, c. S-22. The grounds for judicial intervention, in addition to unreasonable exercises of discretion, include where an exercise of discretion violates the duty of procedural fairness owed in the circumstances, where the Charter or Bill of Rights is infringed, and any case in which the discretionary decision has exceeded the jurisdiction of the official's statutory authority. See generally Mullan, supra note 72 at 100-33. For judicial discussion, see Baker, supra note 14; see also Suresh v. Canada (Minister of Citizenship and Immigration) (2002), 90 C.R.R. (2d) 1.

[1978] 1 S.C.R. 118. 
In my opinion it is important to distinguish between duties imposed on public employees by statutes or regulations having the force of law and obligations prescribed by virtue of their condition of public employees. The members of a disciplinary board are not high public officers but ordinarily civil servants. The Commissioner's directives are no more than directions as to the manner of carrying out their duties in the administration of the institution where they are employed. ${ }^{77}$

The Court's dichotomous understanding of statutory law on the one hand, and soft law on the other, has waxed and waned over the years. The narrow issue in Martineau as to whether guidelines can give rise to procedural obligations was resolved shortly thereafter. The Court in Nicholson v. Haldimond-Norfolk (Regional Municipality) Commissioners of Police, ${ }^{78}$ led by the dissenting justices from Martineau, held that directives and guidelines could give rise to procedural obligations, although this was not necessarily the same as their being treated as "law."

The legal status of ethical guidelines is equally murky. In MacDonald Estate v. Martin ${ }^{79}$ one of the issues considered by the Supreme Court was the status of the Canadian Bar Association's Code of Professional Conduct for lawyers. Justice Sopinka, for the Court, held that a code of ethics could not be considered legally binding, but rather represented "an important statement of public policy." However, in Peet v. Canada (A.G.), ${ }^{80}$ the Federal Court Trial Division characterized the federal government's Conflict of Interest and Post-Employment Code as having the force of "law," and therefore its enforcement was subject to judicial review. The case arose because the Deputy Minister of Forestry determined that an employee of the Ministry had been operating two forestry companies while employed by the government. The employee sought to have this decision judicially reviewed, and the government argued that, because it was an administrative scheme, it was not subject to judicial review. Justice Reed emphasized, since decisions rendered under the Code could have significant consequences for those affected, and following Nicholson, that they could not be rendered in an arbitrary fashion.

The Supreme Court returned to the question of the legal status of guidelines in Little Sisters Book and Art Emporium v. Canada (Minister of Justice), ${ }^{81}$ discussed in more detail below. In that case, the Court was asked to respond to the argument that a Customs Operational Manual, developed to guide Customs officers in exercising their statutory discretion to identify and seize obscene material being imported into Canada, was the source of discriminatory acts undertaken against a gay and lesbian bookstore. Justice Binnie, for the majority, addressed this issue in the following terms:

It is the statutory decision, however, not the manual, that constituted the denial. It is simply not feasible for the courts to review for Charter compliance the vast array of manuals and guides prepared

Ibid. at 129.

[1979] I S.C.R. 311. See also the antecedent to this decision in the UK: Ridge v. Baldwin, [1964] A.C. 40 (H.L.).

[1990] 3 S.C.R. 1235

[1994] 3 F.C. 128.

[2000] 2 S.C.R. 1120 [hereinafter Little Sisters]. 
by the public service for the internal guidance of officials. The courts are concerned with the legality of the decisions, not the quality of the guidebooks, although of course the fate of the two are not unrelated. ${ }^{82}$

If, as Binnie J. suggested in Little Sisters, the "quality of the guidebook" is not unrelated to the "legality of the decisions" of Customs officials, then how can the "vast array of manuals and guides prepared by the public service for the internal guidance of officials" be considered immune from judicial scrutiny and accountability? The Court's distinction is not really one of feasibility so much as legitimacy; there is a similarly vast array of Regulations prepared by the public service which are subject to Charter scrutiny. Legislation and Regulations are subject to Parliamentary accountability and procedural formality (they must be enacted or issued in a particular fashion, published in a particular form, vetted for compliance with constitutional strictures, and are subject to Parliamentary debate). Soft law is subject to no such criteria. Courts cannot treat guidelines as law because to do so would recognize that public administration is subject to laws of its own design, which would offend Canada's constitutional separation of powers. ${ }^{83}$ In our view, to permit public authority to be exercised according to internal and sometimes secret principles and policies, not subject to a fair and accountable process of development or meaningful forms of public review, undermines both the integrity of public administration and the rule of law. ${ }^{84}$

\section{B. SOFT LaW AND JUdicial Review}

Policy guidelines, as emphasized earlier, serve as one of the only bases for accountability available to parties affected by bureaucratic decision-making. It is often impractical for front-line decision-makers to produce detailed reasons for the daily determinations they are called on to make. Administrative law provides a remedy for aggrieved parties who have been subject to discretion exercised for improper purposes or based on irrelevant factors. This remedy is illusory, however, if there is no way to know the proper purposes and relevant factors relating to a particular statutory power. Guidelines provide this information and serve a vital interpretive function in translating legislative authority into administrative action. To date, there appear to be two ways in which guidelines may be subject to judicial review. First, a guideline may be challenged because it purports to bind decision-makers or otherwise lies beyond the jurisdiction of the administrative body which has issued it. ${ }^{85}$ Second, a decision may be challenged based on the fact that the decision-maker either ignored a guideline or allowed her

$82 \quad$ Jbid. at para. 85 .

83 Canada's separation of powers doctrine appears to be gaining in importance. For discussion, see L. Sossin, The Boundaries of Judicial Review: The Law of Justiciability in Canada (Toronto: Thomson Carswell, 1999) at 9-19.

a For discussion of this principle, see U.H. Richardson, “Administrative Policy-Making: Rule of Law or Bureaucracy?" in D. Dyzenhaus, ed., Recrafting the Rule of Law: The Limits of Legal Order (Oxford: Hart Publishing, 1999) 309. 
discretion to be fettered by one. ${ }^{86}$ What appears to be beyond the scope of judicial review are the issues most critical to the accountability and coherence of discretionary decision-making - in other words, the form and content of the guidelines themselves.

It is worth emphasizing that the purpose of guidelines is precisely to enhance coherence and accountability. In his landmark study of administrative discretion, K.C. Davis advocated for rule-making as an important tool for both confining and structuring discretionary power. ${ }^{87}$ His main concern was countering the potential for arbitrary or oppressive uses of administrative discretion. For Davis, plans, rules, findings, reasons, precedents, and a fair informal procedure were all variations on the same theme of greater transparency and accountability. This approach to guidelines has met with some judicial favour. Justice McGillivray, quoting de Smith, observed in Re Hopedale Developments and Town of Oakville that it "'is obviously desirable that a tribunal should openly state any general principles by which it intends to be guided in the exercise of its discretion." $" 88$

Davis envisioned a spectrum of governance measures applicable to discretionary authority, with policy statements shading into interpretive rules and interpretive rules shading into legislative elaboration. As L'Heureux-Dubé J. noted in Baker, "there is no easy distinction to be made between interpretation and the exercise of discretion." ${ }^{89}$

Soft law, while it may be treated as binding internally, cannot give rise to externally enforceable rights. ${ }^{90}$ Canadian jurisprudence recognizes that regulators may, without any specific statutory authority, issue guidelines and other non-binding instruments. ${ }^{91}$ Decision-making bodies and ministries must be cautious not to fetter their own discretion by adopting fixed rules of policy in the absence of specific statutory rulemaking authority. Nor should guidelines be treated as rules to be applied in every case.

See Bezaire v. Windsor Roman Catholic Separate School Board (1992), 9 O.R. (3d) 737 (Div. Ct.) (in which a school board's decision to close nine schools was quashed because neither ministerial nor the school board's policy guidelines, which called for consultations with affected parties, were followed). See also Hammond v. Association Of British Columbia Professional Foresters (1991), 47 Admin. L.R. 20 (B.C. S.C.).

K.C. Davis, Discretionary Justice: A Preliminary Inquiry (Baton Rouge: Louisiana State University Press, 1969).

S.A. de Smith, Judicial Review of Administrative Action (London: Stevens \& Sons, 1959) at 184, as quoted in [1965] 1 O.R. 259 at 263.

Baker, supra note 14 at para. 54 . Mullan explained this relationship in slightly different terms: "Because of their longevity and the expectations built up around them they will be treated as though they were binding both by the agency responsible for promulgating them and the regulated community." See Mullan, supra note 7 at 376. Martineau v. The Matsqui Institution Inmate Disciplinary Board, [1978] 1 S.C.R. 118.

See Ainsley, supra note 6 at 108-109; Re Hopedale Developments and Town of Oakville, [1965] I O.R. 259 at 263 (C.A.); Maple Lodge Farms v. Canada, [1982] 2 S.C.R. 2 at 6-7; Capital Cities Communications v. Canadian Radio-Television Commission, [1978] 2 S.C.R. 141 at 170 [hereinafter Capital Cities]; Friends of the Oldman River Society v. Canada (Minister of Transport), [1992] I S.C.R. 3 at 35; Pezim v. British Columbia (Superintendant of Brokers), [1994] 2 S.C.R. 557 at 596; Law Reform Commission of Canada, Report on Independent Administrative Agencies: A Framework for Decision Making, Report 26 (Ottawa: Law Reform Commission of Canada, 1985) at 29-31. 
Treating a policy statement as a mandatory pronouncement without appropriate statutory authority will justify judicial intervention and a finding of ultra vires. ${ }^{92}$

Discretion may be legitimately guided by policy guidelines, ${ }^{93}$ so long as an affected party is given the opportunity to question the application of the guideline in a deserving case. The Supreme Court held in Capital Cities that, while existing regulations would prevail against policy statements, absent any regulation, the CRTC was obliged to consider its policy statement in making the determination at issue. In reference to the policy guidelines under discussion, Laskin C.J.C., writing for the majority, referred approvingly to democratic input as a justification for giving weight to the guidelines, noting, "the guidelines on this matter were arrived at after extensive hearings at which interested parties were present and made submissions." 94

Two recent Supreme Court decisions have revisited the legal status of policy guidelines and manuals in some detail. In Baker, discussed above in the context of the relationship between ethics and the exercise of discretion, the decision to deny an application for exemption from the Immigration Act on humanitarian and compassionate grounds was challenged. ${ }^{95}$ Baker was an illegal immigrant who had four Canadianborn children during the 11 years she had lived illegally in Canada. The question for the immigration officer was whether the prospect of separating Baker from her children constituted humanitarian and compassionate grounds for exempting her from being deported pursuant to the Immigration Act. The immigration officer denied her application, disclosing in his reasons a number of biases against Baker. The decision of the officer was quashed by the Supreme Court on the basis of bias. The Court also concluded that the officer's decision should be quashed on the grounds that it was an unreasonable exercise of discretion. In this part of the decision, the Court considered the ministry guidelines on which officers were supposed to rely.

Justice L'Heureux-Dubé, writing for the majority in Baker, characterized the Minister's guidelines as "great assistance to the Court in determining whether the reasons ... are supportable. They ... are a useful indicator of what constitutes a reasonable interpretation of the power conferred by the section." ${ }^{96}$ At another point in the judgment, she acknowledged that these guidelines "constitute instructions to immigration officers about how to exercise the discretion delegated to them," 97 and set out the criteria on which discretion should be exercised. In general they provide a decision-making framework for the reasonable exercise of discretion. ${ }^{98}$ In Baker, the Court did not address the legal status of the guidelines per se, but the following passage

\footnotetext{
92 Re E.A. Manning v. Ontario Securities Commission (1995), 23 O.R. (3d) 257 (C.A.). Capital Cities, supra note 91.

Ibid.

Baker, supra note 14.

Ibid. at para. 72 .

Ibid. at para. 16.

In Baker, ibid. the Court held that the decision of an immigration officer was unreasonable. One of the factors considered by the Court in this analysis was the fact that the officer failed to observe the ministry guidelines.
} 
from the judgment suggests that guidelines may be treated, de facto, as limiting the scope of lawful discretion even if de jure they cannot be considered binding per se:

The guidelines also set out the bases upon which the discretion conferred by s. $114(2)$ and the regulations should be exercised. Two different types of criteria that may lead to a positive s. 114(2) decision are outlined - public policy considerations and humanitarian and compassionate grounds. Immigration officers are instructed, under guideline 9.07 , to assure themselves, first, whether a public policy consideration is present, and if there is none, whether humanitarian and compassionate circumstances exist.... Guideline 9.07 states that humanitarian and compassionate grounds will exist if "unusual, undeserved or disproportionate hardship would be caused to the person seeking consideration if he or she had to leave Canada". The guidelines also directly address situations involving family dependency, and emphasize that the requirement that a person leave Canada to apply from abroad may result in hardship for close family members of a Canadian resident, whether parents, children, or others who are close to the claimant, but not related by blood. They note that in such cases, the reasons why the person did not apply from abroad and the existence of family or other support in the person's home country should also be considered.99

Thus, the Court held that it should consider the guidelines in determining whether the exercise of discretion in a given context was "reasonable." ${ }^{100}$ That the decision taken in that case was at odds with the guidelines was held to be one of several grounds for quashing it as an unreasonable exercise of discretion. ${ }^{101}$

The Court focused more directly on the legal significance of guidelines in the context of administrative discretion again in Little Sisters. ${ }^{102}$ Little Sisters is a lesbian and gay bookshop in Vancouver whose owners claimed that their Charter rights were violated over a period of years by the targeting actions of Customs officers in seizing material which Little Sisters sought to import across the border. The Customs $\mathrm{Act}^{103}$ authorized officers to seize material that met the threshold for obscenity set out in the Criminal Code - a standard discussed by the Supreme Court in R. v. Butler. ${ }^{104}$

After a complex trial, the judge concluded not only that Customs officials had wrongly delayed, confiscated, destroyed, damaged, prohibited or misclassified materials imported by the appellant on numerous occasions, but that these errors were caused "by the systemic targeting of Little Sisters' importations in the [Vancouver] Customs Mail Centre." 105 The trial judge found that the Customs Act, to the extent it violated Charter rights, was a reasonable infringement under s. 1; the trial judge did, however,

Jbid. at para. 17.

Ibid. at paras. 74-75.

Ibid.

Little Sisters, supra note 81 . For a broader discussion of the significance of Little Sisters, see L. Sossin, "Discretion Unbound: Reconciling the Charter and Soft Law" (2002) 45 Can. Pub. Admin. [forthcoming]. See also B. Ryder, "The Little Sisters Case, Administrative Censorship and Obscenity Law" (2001) 39 Osgoode Hall L.J. 207.

R.S.C. 1985, c. C-1.

[1992] 1 S.C.R. 452.

(1996), 18 B.C.L.R. (3d) 241 at para. 108 (S.C.). 
issue a declaration that the application of the legislation against Little Sisters violated ss. 15 and 2(b) of the Charter.

Justice Binnie, writing for the majority of the Supreme Court, characterized the administration of the Customs Act as oppressive and dismissive of Little Sisters' freedom of expression and concluded that its effect - whether intended or not - was to isolate and disparage the appellants on the basis of their sexual orientation. ${ }^{106}$ The Court recognized that a source of the targeting of Little Sisters lay in the Operations Manual (Memorandum D9-1-1) which was relied upon by Customs officials. To take but one example, the Manual suggested that all acts of anal penetration violated the obscenity standard in direct contradiction of prevailing constitutional standards and the position of the Department of Justice. Notwithstanding the evidence that Customs officers followed the Manual in virtually every instance, Binnie J. was unwilling to subject this non-legislative instrument to Charter scrutiny, in part because, for reasons discussed earlier, such non-legislative guidelines cannot be construed as binding:

The trial judge concluded that Customs' failure to make Memorandum D9-1-1 conform to the Justice Department opinion on the definition of obscenity violated the appellants' Charter rights. However, I agree with the British Columbia Court of Appeal that the trial judge put too much weight on the Memorandum, which was nothing more than an internal administrative aid to Customs inspectors. It was not law. It could never have been relied upon by Customs in court to defend a challenged prohibition. The failure of Customs to keep the document updated is deplorable public administration, because use of the defective guide led to erroneous decisions that imposed an unnecessary administrative burden and cost on importers and Customs officers alike. Where an importer could not have afforded to carry the fight to the courts a defective Memorandum D9-1-1 may have directly contributed to a denial of constitutional rights. It is the statutory decision, however, not the manual. that constituted the denial. ${ }^{107}$

In our view, the attempt to construct a watertight boundary between what constitutes "deplorable public administration" and what constitutes a breach of "law" is, once again, an artificial and ill-conceived exercise. A more pragmatic approach to the law of guidelines is desirable. If guidelines, ethical codes, or even administrative practices for that matter, exert significant influence over the exercise of discretion, then they must be seen as "law," albeit soft law. As such, they should adhere to a set of minimal procedural requirements governing their content and the process by which they are developed and disseminated. The nature of these legal requirements is discussed below.

Justice Binnie himself appeared to acknowledge this interplay between legislative and non-legislative factors affecting discretion in Little Sisters:

The public service responds to ministerial direction with no less alacrity than it responds to statute or regulation. In short, an importer's rights may be protected in fact by statute, regulation. ministerial 
direction or even departmental practice. What is crucial, at the end of the day, is that Charter rights are in fact respected. The modalities for achieving that objective will vary with the context. ${ }^{108}$

More importantly, no law and no constitutionally-mandated set of procedures can obviate the importance of discretion and the difficulty in holding public officials accountable for how discretion is exercised. The long history of trying to sweep discretion away by increasingly complex laws and dense procedures does not suggest a basis for optimism that this strategy alone will result in more democratic accountability or fewer abuses of discretion. ${ }^{109}$ Rather, it often has had the effect of submerging the exercise of discretion and providing no public venue or meaningful standards for its scrutiny.

As cases such as Baker and Little Sisters illustrate, although courts have often been unwilling to treat guidelines and codes as law, soft law has significant potential to serve as a conduit for a judicial-executive dialogue concerning the nature and scope of bureaucratic decision-making. ${ }^{110}$ Soft law may be used, as in the Operational Memorandum to immigration officers following Baker, to communicate new judicial standards to bureaucratic decision-makers. Such discretionary standards and guidelines, in turn, are considered as part of the decision-maker's administrative expertise, which attracts deference from the court when decisions are challenged. In this way, soft law facilitates an important and dynamic role for courts in the regulation of bureaucratic decision-making. As long as soft law is not considered part of the legal regime governing the exercise of discretion, the accountability function of judicial scrutiny will be significantly undermined.

\section{CONClusion}

Soft law may be said to bridge law and policy. It has the potential to enhance the coherence and fairness of bureaucratic decision-making. To realize this potential, we have suggested that it is necessary to overcome the misleading dichotomy between ethics and discretionary authority on the one hand, and between law and guidelines on the other. All guidelines, whether they relate to conflicts of interest or elaborating the meaning of obscenity or compassionate grounds, should conform to a set of procedural and substantive criteria, and be subject to political justification and judicial scrutiny. While a full elaboration of such criteria is beyond the scope of this study, we suggest the following principles which may serve as a departure point for a discussion of the role of guidelines in the legal regulation of administrative decision-making.

First, governments should be under a positive mandate to develop guidelines wherever a specific discretion has been granted. Broader guidelines should be issued

It:

(x)
Ibid. at para. 138.

For a broader discussion of the relationship between law and discretion in the Canadian context, see L. Sossin, "The Politics of Discretion: Toward a Critical Theory of Public Administration" (1992) 36 Can. Pub. Admin. 364; and L. Sossin. "Redistributing Democracy: An Inquiry into Authority, Discretion and the Possibility of Engagement in the Welfare State" (1994) 26 Ottawa L. Rev. L. See generally K. Hawkins, ed., The Uses of Discretion (Oxford: Clarendon Press, 1992). For a discussion of this aspect of soft law, see Sossin, supra note 102. 
across administrative settings which clearly set out the various factors which may not be considered by decision-makers, including partisan and discriminatory factors, ideological factors, and pecuniary factors (that is to say, conflicts of interest). In this fashion, ethical concerns, and concerns regarding the impartiality of decision-makers, would not be artificially segregated. "I Second, unless it would be contrary to the public interest, guidelines and codes should be available to the public and, where feasible, developed with input from citizen and stakeholder groups and interested members of the public at large. Third, guidelines should be subject to a common set of government-wide standards as to form and presentation, and should be vetted by the Ministry's legal department for compliance with statutory standards and purposes, as well as compliance with the Charter and other legal requirements. Fourth, there should be written reasons kept for any departures from guidelines or ethical codes, or for any resolution of "hard cases" in the application of those guidelines, which could serve as a catalyst for training initiatives and provide a record for any potential judicial review.

These minimal standards would have the effect of rendering guidelines and codes of ethics more coherent but no less flexible. By subjecting guidelines to greater public scrutiny and less legal uncertainty, governments will have to better justify the rules by which public officials operate, and defend the political preferences these rules reflect. In the final analysis, public administration is not principally a field of technical expertise or ethical rules, but rather a forum for making and implementing hard choices in the public interest. Soft law has the potential to ensure those choices are made in an accountable and justifiable fashion, but only if we are willing to discard a set of legal fictions about bureaucratic decision-making. 